\title{
Gender diversity reporting, performance, and exogenous shocks: evidence from New Zealand
}

\section{Geeta Duppati*}

\author{
Waikato Management School, \\ The University of Waikato, \\ Hamilton, New Zealand \\ Email: geeta.duppati@waikato.ac.nz \\ *Corresponding author
}

\section{Narendar V. Rao}

College of Business and Management,

Northeastern Illinois University,

Chicago, Illinois, USA

Email:nvrao@neiu.edu

\section{Frank Scrimgeour}

\author{
Waikato Management School, \\ The University of Waikato, \\ Hamilton, New Zealand \\ Email: frank.scrimgeour@waikato.ac.nz
}

\section{Neha Matlani}

Shri Ram College of Commerce, University of Delhi, New Delhi, India

Email: neha.matlani@yahoo.com

\begin{abstract}
Whether and how gender diversity on corporate boards affects corporate performance has been the focus of public debate, academic research, and government agenda for more than a decade. Though having women on corporate boards was previously considered a form of tokenism and a matter of corporate image, gender diversity is increasingly perceived as a value-driver in organisations. New Zealand has one of the lowest rates of women on publicly-listed company boards in the western world. This study utilised a sample of (New Zealand stock exchange) NZX firms to explore whether or not firms with women on the corporate boards of directors financially outperform companies with all-male boards. Drawing upon critical mass theory and agency theory literature, the study analyses 69 public companies over the period from 2005 to 2016. Results confirm that women on corporate boards tend to exert a positive influence on companies that is reflected in corporate financial measures. Several comparative results are presented for pre- and post-reporting requirement; pre-, during- and post-global financial crisis windows.
\end{abstract}


Keywords: gender diversity; corporate board diversity; financial performance and gender; New Zealand; corporate governance; agency theory; critical mass theory.

Reference to this paper should be made as follows: Duppati, G., Rao, N.V., Scrimgeour, F. and Matlani, N. (2019) 'Gender diversity reporting, performance, and exogenous shocks: evidence from New Zealand', Int. J. Comparative Management, Vol. 2, Nos. 3/4, pp.203-228.

Biographical notes: Geeta Duppati is a Senior Lecturer at the Department of Finance, Waikato Management School, Hamilton, New Zealand. Her current research interests are primarily concerned with corporate governance, asset pricing, corporate social responsibility, foreign investments, and mergers and acquisitions. She has several publications in the area and is involved in professional development work with large corporates in India. Recently, in 2017, she was awarded by Accounting and Finance Association of Australia and New Zealand (AFAANZ) funding.

Narendar V. Rao is a Senior Professor of Finance at Northeastern Illinois University, Chicago. His academic interests include mergers and acquisitions, Islamic finance, capital budgeting, and corporate valuation. He has published academic articles in a wide-range of management and finance journals, including Journal of Financial and Strategic Decisions, Eurasian Business Review, International Journal of Business and Globalisation, Cogent Business \& Management, and Asia-Pacific Journal of Management Research and Innovation. He has also presented his research at various national and international conferences.

Frank Scrimgeour is the Head of School of Accounting, Economics and Finance and a Professor of Economics at the University of Waikato. He has contributed numerous research publications pertaining to the economics of agriculture and agribusiness, the economics of the environment, the economics of regional development and Maori development and financial economics and governance. He is a former President of the New Zealand Association of Economists and is currently President of the New Zealand Agricultural and Resource Economics Society. He joined the University of Waikato as an Economics Lecturer in 1989. Former responsibilities at Waikato include Director of the Management Centre and chairperson of the Economics, Finance and Tourism departments.

Neha Matlani is an alumna of Shri Ram College of Commerce and Delhi School of Economics, is a gold medallist in the MCom Examination (2008) of the University of Delhi. She works as an Assistant Professor of Commerce and Business Studies at the Shri Ram College of Commerce, University of Delhi, India. She holds a $\mathrm{PhD}$ in Commerce (Corporate Governance) from Delhi School of Economics, University of Delhi. She pursued a Master of Philosophy, Master of Commerce and Bachelor of Commerce (Honours) at University of Delhi and have topped the aforementioned degrees with scholarships. Her areas of specialisation are corporate governance and organisational behaviour. She has a couple of articles published in journals of repute and has presented papers in various international conferences. 


\section{Introduction}

Historically, the shareholders of public companies around the world have tended to elect all-male directors to represent their interests on corporate boards. However, this is increasingly changing as women move into spheres previously considered all-male domains. Women now form their own corporations and hold significant business positions that place them in line for board-level corporate directorships; additionally, society's expectations have changed as stakeholders have become more vocal in their support for diversity initiatives and commitment to social responsibility. Indeed, gender diversity on corporate boards of directors has been the focus of public debate, academic research, and government agenda for more than a decade now (Terjesen et al., 2009; Kirsch, 2018; Thams et al., 2018; Yang et al., 2019). Although it was previously thought of as a social issue, evidence of tokenism, and a matter of corporate image, gender diversity is increasingly perceived as a value-driver in organisational issues. In general, ethnic and gender diversity on corporate boards is considered to be beneficial, because directors from varied backgrounds bring different perspectives to the myriad challenges companies face. The hope is that the varying perspectives will enable companies to formulate more effective, multi-faceted solutions. Robinson and Dechant (1997) initiated the 'business case for diversity'. They argued that board gender diversity improves board decision making, which in turn positively impacts its financial performance. Nevertheless, studies examining the impact of gender diversity on corporate boards have not achieved unanimity. Additionally, most empirical studies have been based on US data, with a paucity of studies using non-US data. This study attempts to further the understanding of the impact of gender diversity on corporate boards, and bridge the gap in the literature using data collected from non-US companies, by taking a look at the impact of gender diversity on boards over an extended period of time.

\subsection{A review of literature - gender diversity on corporate boards}

While the presence of gender diversity on boards is assumed to produce a positive impact on board effectiveness (Adams et al., 2015), not all studies to date have supported this notion. Some researchers say that gender diversity is likely to increase the chances of superior performance, while others say it makes no difference, and a few say that the presence of women on corporate boards has a deleterious effect. The empirical evidence linking gender diversity to firm financial performance is equivocal. Adams and Ferreira (2009), Ahern and Dittmar (2012) and Yang et al. (2019) found a negative relationship between gender diversity and firm performance. Their studies suggest that female presence on corporate boards may lead to over-monitoring, particularly in companies that already have strong governance systems in place. Evaluating a sample of firms listed on the Indonesian Stock Exchange, Darmadi (2011) found that the presence of women directors had a negative impact on return on assets (ROA) and Tobin's Q (TQ). A study by Dobbin and Jung (2011) found that an increase in gender diversity on corporate boards tends to be followed by a significant decrease in stock value. In contrast, Pletzer et al. (2015) concluded that a higher proportion of female representation on corporate boards is not associated with a detrimental effect on firm performance. Other studies found no conclusive link between board gender diversity and financial performance. Wang and Clift (2009) report that board gender diversity does not significantly influence accounting 
measures of financial performance, such as ROA and return on equity (ROE). Based on an analysis of S\&P 500 firms, Carter et al. (2010) did not find a significant relationship between board gender and ethnic diversity and financial performance. Marimuthu and Kolandaisamy (2009) found insignificant relationships between board gender diversity and both ROA and ROE over a four-year period spanning 2000-2006. Other studies have found no influence of gender diversity on firm financial performance (Mohan and Chen, 2004; Moncrief et al., 2000; Rose, 2007; Shrader et al., 1997; Smith et al., 2006; Wang and Clift, 2009). Clearly, the studies above either found no link between performance and board diversity or showed a negative impact.

Although the studies have not been unanimous in establishing a positive link between female board diversity, board effectiveness, and improved firm financial performance, the preponderance of studies have supported the idea that gender diversity on a board enhances financial performance. Among Fortune 1000 firms, Carter et al. (2003) reported a positive relationship between the presence of women on company boards and firm value as measured by TQ. Erhardt et al. (2003) observed similar results based on a sample of 127 large US corporations, and found that the percentage of female directors is positively associated with two financial performance indicators: return on investment (ROI) and ROA. A four-year study by the Catalyst Organization (2011) followed Fortune 500 women board directors from 2004 to 2008. The study supported the link between board gender diversity and financial performance. Using return on invested capital (ROIC) as a measure of value creation and financial performance, the Catalyst study showed that those Fortune 500 firms which had the highest female board representation outperformed those Fortune 500 firms with the least (or zero) female board representation.

While the issue of board gender diversity has attracted growing research interest in recent years, most empirical results are based on US data. Campbell and Minguez-Vera (2008) add to a growing number of non-US studies by investigating the link between the gender diversity of the board and firm financial performance in Spain, a country which historically has had minimal female participation in the workforce, but which has now introduced legislation to improve equality of opportunities. The study investigates the topic using panel data analysis and find that gender diversity - as measured by the percentage of women on the board and by the Blau and Shannon indices - has a positive effect on firm value and that the opposite causal relationship is not significant. Findings suggest that investors in Spain do not penalise firms which increase their female board membership and that greater gender diversity may generate economic gains.

Another non US data based study, addresses the following question: does an increased number of women corporate boards result in a build-up of critical mass that substantially contributes to firm innovation? The aim is to test if 'at least three women' could constitute the desired critical mass by identifying different minorities of women directors (one woman, two women and at least three women). Tests are conducted on a sample of 317 Norwegian firms. The results suggest that attaining critical mass - going from one or two women (a few tokens) to at least three women (consistent minority) makes it possible to enhance the level of firm innovation. Moreover, the results show that the relationship between the critical mass of women directors and the level of firm innovation is mediated by board strategic tasks (Torchia et al., 2011). A similar study based on critical mass theory and with the help of a hand-collected panel dataset of 151 listed German firms for the years 2000-2005, explores whether the link between gender diversity and firm performance follows a U-shape. Controlling for reversed 
causality, the study finds evidence for gender diversity to at first negatively affect firm performance and - only after a 'critical mass' of about $30 \%$ women has been reached - to be associated with higher firm performance than completely male boards. Given our sample firms, the critical mass of $30 \%$ women translates into an absolute number of about three women on the board and hence supports recent studies on a corresponding 'magic number' of women in the boardroom (Joecks et al., 2013).

Post and Byron (2015) combined the results of 140 studies in a meta-analysis; their work showed that women on boards tended to positively affect accounting returns, but did not seem to have a significant influence on market performance. A number of studies which link female board representation to financial performance, for example, Julizaerma and Sori (2012) found a positive relationship between women on the board and firm performance in Malaysian companies. Other studies that have documented a positive relationship between female representation on boards and firm financial performance include (Bonn, 2004; Krishnan and Park, 2005; Nguyen and Faff, 2007; Duppati et al., 2019; Martínez and Rambaud, 2019).

Some studies have found that women's presence on boards generates a negative impact on firm performance. In a multicounty study of Norwegian setting, Yang et al. (2019) found a negative impact of the mandated female representation on financial performance and on firm risk. Mínguez-Vera and Martin (2011) analysed the gender diversity of a sample of Spanish small and medium enterprises. They explained the result of negative link may be due to less risky strategies implemented by women directors. This finding is interesting because it sheds light on how women can affect the functioning of a board. It also found that family firms and firms with a financial institution as the main shareholder tend to have more women on the board. In contract, another recent study from Spain found that the increasing number of women on boards is positively related to higher financial performance (Martínez and Rambaud, 2019).

In summary, the argument for greater female representation on corporate boards tends to be based on four criteria: enhanced performance, access to a wider talent pool, market responsiveness, and improved corporate governance (Doldor et al., 2012; Kirsch, 2018).

\subsection{The argument for studying New Zealand stock exchange (NZX) companies}

Given the wide array of findings in studies examining the potential impact of gender diversity on corporate boards, it makes sense that a variety of studies have tried to explain the differences in the divergent findings. Some of the studies showed negative or zero impact from gender diversity on corporate boards. This could have been due to tokenism. When boards studied do not have a large enough number of women seated at the conference table, i.e., just one or two 'token' women, gender impact studies may therefore not be valid, because the token women tend not to find a strong enough voice to make an impact. Another interesting finding came from Low et al.'s (2015) study, which noted that positive effects of gender diversity on boards appeared to be diminished in countries with higher female economic participation and empowerment. This suggests that societies with more equal relationships between men and women are less likely to have gender-distinctive anomalies. Further, the study concluded that cultural factors may play a role in the effectiveness of women directors. Based on these findings, this study proposes that countries with lower female economic participation and empowerment are relevant and compelling subjects for gender diversity studies. 
New Zealand is therefore an excellent choice for examination. The country has one of the lowest rates of women on publicly-listed company boards in the western world (New Zealand Institute of Directors). In 2016, just 17\% of public New Zealand companies had women board members. Given the low percentage of female board diversity and economic representation in New Zealand, the companies with female board representation should offer a stark contrast to (New Zealand stock exchange) NZX listed firms without female board representation. This study utilised a sample of NZX firms to explore whether or not firms with women on the corporate boards of directors financially outperform companies with all-male boards. Additionally, in contrast with previous studies, this study has the benefit of a longer period of study than those above. This study considered 69 public companies over a very recent and longer time period (2005-2016). Additionally, this study addressed the endogeneity issue in a systematic way. As a result, the findings of this study suggest significant influence of gender diversity on corporate performance at a 5\% level of significance for the period 2005-2016, while the results show a $1 \%$ level of significance in the post-financial crisis period. The study utilised a theoretical framework using critical mass theory and agency theory from the New Zealand context.

In general, the move toward greater gender diversity on corporate boards has largely been initiated by shareholders and outside organisations. Kumar and Zattoni (2016) discussed a number of recent shareholder actions targeting individual firms. Additionally, advocacy organisations such as Catalyst have lobbied for government quotas and soft-law principles, and have pressured public companies to voluntarily adopt higher board gender diversity standards (http://www.catalyst.org). For the past 25 years, the Global Women Research and Education Institute in Washington, DC, has sponsored a Global Summit of Women to bring together public, private and non-profit leaders under a shared vision of 'dramatically expanding women's economic opportunities [around] the world' (http://www.globewomen.org). In 2011, corporate women directors international (CWDI), one of the divisions of GlobeWomen, identified three main global strategies to improve women's representation on corporate boards. They include:

1 a call for government-mandated quotas of women on corporate boards

2 a call for male corporate leaders to emerge as champions of women who join corporate boards

a a recognition from male corporate leaders that women on corporate boards boost corporate reputations

3 a call to the world's exchanges to mandate the reporting of board diversity in corporate governance codes.

These demographic and substantive strategies have been quite persuasive to countries and their stock exchanges. The perceived need to increase the representation of women on corporate boards is now concomitant with the pressure to improve corporate governance.

The CWDI strategies above have successfully pressured a number of governments around the world to issue quotas or soft regulations that encourage board gender diversity. In terms of legal quotas, Norway was the first country to introduce a gender quota law for boards of directors. Since the passage of this 2003 Norwegian quota law, several European countries including Spain, France, Iceland, Italy, the Netherlands, Germany and Belgium have followed suit with legislated targets. In general, quotas seem 
to be growing in popularity as a means of conveying that certain governments or exchanges are forward-thinking, transparent and modern. The impact of these quotas seems to be a moot point, as the movement for legislated targets plods forward regardless of such exigent considerations. Wood et al.'s (2013) study pointed out that these quotas have neither affected the quality of female appointments, nor have they impacted company performance negatively. Nevertheless, some countries cannot abide by quotas. For example, New Zealand's seemingly widespread cultural antipathy to quotas has been well documented (New Zealand Human Rights Commission, 2012). Rather than issuing quotas, New Zealand has followed the examples of Australia (2011), the UK (2010) and at least 13 other countries since 2003 (Human Rights Commission, 2012) in issuing soft recommendations based on the 'comply or explain' principle to promote female representation on boards.

In large part, the emergence of female representation within New Zealand's publicly held companies came about following the new diversity reporting regulations announced by the NZX in 2012. In New Zealand, gender diversity reporting is the preferred choice of the three strategies outlined earlier. It has a strong element of public relations and is aimed at improving transparency. Its rationale has usually been tied to the 'business case' argument (Bilimoria, 2000), which looks at whether the presence of women on boards improves the overall financial condition and reputation of companies (Eversheds LLP, 2011). The 2012 regulatory changes on gender diversity reporting for the listed New Zealand companies now require NZX companies to include gender diversity reporting in their annual reports. The reporting should include a breakdown of the gender composition of the boards of directors and corporate officers in annual reports. In addition, companies with a formal diversity policy are required to provide an evaluation of their performance with respect to these policies in all annual reports ending on or after 31 December 2012. This requirement may be read as a way to gently encourage board diversity.

While the logic outlined above offers a compelling argument for studying gender diversity on New Zealand's corporate boards, the logic is further compounded by way of corporate governance theory (Kim et al., 2009), whereby the structure of a board exerts a strong influence on the actions of the board, and by extension, a firm's financial performance. Not only should a board structured to include gender diversity act differently from all-male boards, with different financial results, but this should be particularly evident in light of a trigger event. New Zealand has one of the lowest rates of female representation on its corporate boards. In 2012, NZX-listed companies' largely all-male boards faced the trigger event of mandated diversity reporting requirements. The requirement triggered emerging, gender-diverse boards of directors. To further compound the distinction, the recent global financial crisis (GFC) was both a natural occurrence and exogenous event that created an ideal circumstance for evaluating the results of emergent gender diversity on corporate boards. According to Essen et al. (2013), governance mechanisms operate differently in crisis and non-crisis periods. The tendency to respond to a crisis with more stringent rules might be counter-productive since such measures may compromise executives' ability to respond appropriately to shocks. Thus, during a crisis, practitioners are encouraged to optimise rather than maximise their governance choices (Essen et al., 2013), which likely has had implications on the performance of firms. Using this logic, the GFC provides an interesting opportunity to examine companies' efforts to optimise governance choices. The insights gained by this study should be of interest to policymakers, regulators, practitioners and academicians. 
Shareholders and potential investors may take the findings into consideration when deciding whether or not to invest in corporations with women board members. Further, examining the data on gender diversity over time, during times that encompass periods of relative financial crisis, provides an opportunity to evaluate the conditions under which female board representation's influence on leadership may deliver the best corporate performance. The data should highlight periods in which gender diversity on a board may be less useful.

In summary, the reasons that New Zealand makes an excellent choice of study are: first, the country's cultural lack of women on the majority of corporate boards should contrast sharply with the situation of emergent, gender diverse boards on the rise due to recent reporting requirements; second, the fact that the country suffered through the GFC presents an opportune moment in time in which to study board decisions aimed at optimising governance choices; and third, the empirical investigation enables a longer-term examination than most previous studies, encompassing three periods: the pre-financial crisis period (2005-2007), during the financial crisis period (2008-2009) and the post-crisis period (2010-2016).

Three important research questions are pursued in this study:

RQ1 Does gender diversity on corporate boards affect corporate performance?

RQ2 What has been the impact of New Zealand's gender diversity reporting requirement?

RQ3 Are the effects of gender diversity on performance comparable in the three crisis periods, pre, during, and post-financial crisis?

The remainder of this study is organised as follows: Section 2 explains the theoretical background and hypothesis in the study. Section 3 describes this study's data source, examination periods, selection and definition of variables, and the method employed. Section 4 addresses empirical results, and Section 5 provides concluding remarks and limitations and suggestions for future research.

\section{Theoretical background and hypothesis}

Gender diversity on corporate board of directors has been the focus of public debate, academia, and government policy agenda for more than a decade now (Terjesen et al., 2009; Thams et al., 2018; Yang et al., 2019). Although it was previously thought of as a social issue and a matter of corporate image, gender diversity is increasingly perceived as a value-driver in organisational issues. Robinson and Dechant (1997) initiate this so-called 'business case for diversity' and argue that board gender diversity improves board decision making, which in turn positively impacts corporate financial performance.

In order to understand and explain the linkages between board characteristics and firm level performance, two main theories have been considered in this study: agency theory and critical mass theory.

\subsection{Agency theory}

Agency theory deals with the conflict of interest between principals and agents. It therefore focuses on the monitoring and control function of the board. It also has been 
used to argue that diversity increases board independence. That is to say, people with a different gender, ethnicity or cultural background might ask questions that are unlikely to come from directors with more traditional, or homogenous, backgrounds (Carter et al., 2003). Having an conducive atmosphere that permits wide-ranging contributions enables all directors to think more independently and perhaps deviate, as needed, from the previously-accepted, traditional viewpoints. Thus, the independent thinking of board members is one consequence of board diversity. Later, Jurkus et al. (2011) argued that board diversity reduces agency costs which, in turn, improve firm performance, especially for those firms with a weak governance structure. Gul et al. (2011) suggested that a firm with weak governance can partially remedy the situation by having a gender-diverse board. Given the positive impact of diverse viewpoints through ethnic or cultural diversity on all-male corporate boards, it stands to reason that increasing board diversity by including women should enhance the quality of board decisions (Shanmuganathan, 2018)

Empirical evidence shows that women directors tend to be more active in monitoring corporate activities. For instance, Adams and Ferreira (2009) and Gul et al. (2008) found that gender-diverse boards demand more audit efforts and managerial accountability. The effects of board gender diversity on corporate decisions also depend on firms' governance quality. In well-governed firms, board gender diversity may be detrimental to firm value due to excess monitoring (Adams and Ferreira, 2009). Agency theory (Fama, 1980; Fama and Jensen, 1983; Jensen and Meckling, 1976) supports any mechanisms that solve conflict between managers and owners. Given that boards of directors' decisions are seen as a good tool for aligning respective competing interests, it can be assumed that larger boards can exercise better control on managers than those smaller ones (Donaldson, 1990; Donaldson and Preston, 1995; Freeman, 2010).

Extant research on the risk-taking behaviour of women has mostly been consistent with risk avoidance (Bernasek and Shwiff, 2001; Hudgens and Fatkin, 1985; Sunden and Surette, 1998). Croson and Gneezy (2009) and Niederle and Vesterlund (2007) argue that women display risk aversion because they prefer less competitive situations; however, in Johnson and Powell's (1994) review of the literature on male and female decision making, they find no difference in the risk-taking of women vs. men. They do, however, argue that stereotypes of women in non-managerial roles are imposed on women in managerial roles. Dwyer et al. (2002) suggest that the relationship between gender and risk-taking may be a function of knowledge disparities. Weber and Zulehner (2010) show that start-ups by women have higher chances of survival than start-ups by men. Adams and Ferreira (2009) showed that female directors also are better monitors, although they documented a negative relationship between gender diversity and firm performance. With already established gender differences in risk-taking and economic decisions, gender differences should contribute to diverse points of view and hence positively impact innovation.

\subsection{Critical mass theory}

Critical mass theory has been widely explored in the women and corporate governance literature. It discusses a critical mass of people necessary to achieve an end. The applied critical mass theory proposes that a certain critical mass of female directors is necessary in order to realise the positive effects of gender diversity. The more women on a board, 
the more likely that they would be confident in asserting issues of interest to them, such as a firm's level of corporate social responsibility (CSR). Low et al. (2015) reported that a critical mass of female directors on the board had a positive impact on performance, as measured by ROE. A Canadian study of private sector, public sector, and not-for-profit boards (Brown et al., 2002) revealed that boards with a critical mass of three or more women are significantly different than all-male boards. Sjåfjell (2014) emphasised that if critical mass is achieved, boardroom gender diversity will have a positive effect on board effectiveness and financial performance. Proponents use critical mass theory to support the argument that if necessary, board diversity should be achieved through mandatory legislation, because such diversity is good for the financial strength of companies, and therefore positively impacts employees and shareholders. Adams and Ferreira (2009) showed that boards with balanced gender representation can allocate more time to board monitoring. Their study supports the theory that a more diverse board may be more independent from top managers.

Empirical evidence shows that women directors tend to be more active in monitoring corporate activities. For instance, studies by both Gul et al. (2008) and Adams and Ferreira (2009) showed that gender-diverse boards demand more audit efforts and managerial accountability. The effects of board gender diversity on corporate decisions also depend on the quality of the firms' governance. In well-governed firms, board gender diversity can be detrimental to firm value due to unnecessary excess monitoring (Adams and Ferreira, 2009). Critical mass is especially important because women and others who are different from the dominant group are likely to face tokenism when they are the sole representatives of their group characteristic (Kanter, 1977). Consequently, their views may not be given much credence. The dominant group, e.g., Caucasian males, may tend to see women first as female, embodying the sex role stereotype, and only later as individuals. This makes it difficult for women directors to be heard and listened to on an equal basis with male board members. Erkut et al. (2008) found that such issues are reduced when there is more than one female director. They refer to a critical mass that is formed when there are two or more women board members. They found that when the critical mass exists, women directors are likely to be taken seriously by their male counterparts. In addition, the male board members are unlikely in such a situation to dismiss the comments made by their women colleagues on the board. Additionally, the Erkut et al. (2008) study showed that the real change occurs when there are three or more women on the board. Three plus women directors tend to make women directors feel much more comfortable in expressing their views candidly at board meetings without having to ponder how the male directors might react. When a critical mass of female directors are present in the boardroom, their male counterparts may make a serious effort to engage them in discussion and solicit their views on important corporate matters, particularly when a vote is required.

\section{Data source and methods}

Using the theories in corporate governance literature: agency and critical mass theory, the present study provides evidence on the association between gender diversity and the financial performance of firms listed on the NZX. A total of 69 firms were studied from 2005-2016. The firm-year observations that did not have three years of continuous data have been eliminated in order to reduce error. The final panel data is strongly balanced 
(Bansal and Sharma, 2019). Company performance data and other accounting data for explanatory variables were downloaded from Thomson One Banker (Worldscopeglobal database). Data regarding female representation on boards and board size was collected from the annual reports of each observed company. All of the annual reports were downloaded from companies' official websites. Table 1 describes the dependent and independent variables used in the study.

Table 1 Description of variables used in the study

\begin{tabular}{ll}
\hline Determinants & \multicolumn{1}{c}{ Operationalisation } \\
\hline $\begin{array}{l}\text { Dependent (firm performance variable) } \\
\text { TQ ratio }\end{array}$ & $\begin{array}{l}\text { TQ ratio is the sum of the market value of equity and the book } \\
\text { value of total debt divided by the book value of total assets. }\end{array}$ \\
$\begin{array}{l}\text { Independent corporate governance variables and performance variables } \\
\text { Gender diversity } \\
\text { (female) }\end{array}$ & The proportion of female directors on the board. \\
Board size & $\begin{array}{l}\text { Board size is the natural logarithm of board size. Board size is the } \\
\text { total number of directors on the board. } \\
\text { Beta }\end{array}$ \\
$\begin{array}{l}\text { Sales to total assets } \\
\text { (STA) }\end{array}$ & $\begin{array}{l}\text { STA is expressed as sales divided by total assets. } \\
\text { Slack }\end{array}$ \\
Control variables & Financial slack (i.e., lower leverage). \\
Firm age & The natural logarithm of firm age (lnfage) is used in the models. \\
& $\begin{array}{l}\text { Firm age is the number of years from the time that the company } \\
\text { incorporated } \\
\text { The natural logarithm of firm size (lnfsize) is used in the models. }\end{array}$ \\
Firm size & Firm size is the book value of total assets.
\end{tabular}

Techniques used include the quantile regression (QR) approach and multivariate OLS regression techniques. This research methodology is appropriate in identifying the effects of a specific intervention. In this case, it is the requirement of the NZX regarding reporting on gender diversity. A comparison is then conducted between the outcomes before and after the intervention for intervention-affected groups, and contrasted with those unaffected by the intervention (Bertrand et al., 2004).

\subsection{Model estimation: $Q R$}

The constant-coefficient regression models, such as the OLS and least absolute deviations (LAD), have been extensively applied in the extant empirical studies (Basu and Markov, 2004). At times, they also have been used to provide a robustness check to gauge the potential undue influence of outliers (Ely and Waymire, 1999; Mansi et al., 2004). Both statistical approaches provide only one measure of the central distribution tendency of the dependent variable. However, these methods fail to address the behaviour of the dependent variable in the tail regions. To address this issue, various random coefficient models have emerged as viable alternatives in the field of statistical application (Li and Hwang, 2011). 
QR was first proposed by Koenker and Bassett (1978). It extends the classical least squares estimation of the conditional mean to a collection of models for different conditional quantile functions and captures systematic influences of conditioning variables on the location, scale and shape of the conditional distribution of the response. Therefore, implementing the QR model allowed us to significantly extend a constant coefficient instead of using the OLS or LAD methods that confine the effects of conditioning to a location shift (Koenker and Hallock, 2001). QR is applied when an estimate of the various quantiles in a population is desired, and also has several other useful features. First, the QR estimator minimises the weighted sum of absolute residuals rather than the sum of squared residuals. Thus, the estimated coefficient vector is not sensitive to outliers. Second, a QR model employs a linear programming representation and thereby simplifies examination. Third, this form of analysis is particularly useful when the conditional distribution does not have a standard shape, such as an asymmetric, fat-tailed, or truncated distribution. The QR approach can thus obtain a much more complete view of the effects of explanatory variables on the dependent variable. The basic QR model specifies the conditional quantile as a linear function of explanatory variables, and is given by:

$$
\begin{aligned}
& y_{i}=x_{i}^{\prime} \beta_{\theta}+\mu_{\theta i}, \quad 0<\theta<1 \\
& \text { Quant }_{\theta}\left(y_{i} \mid x_{i}\right)=x_{i} \beta_{\theta}
\end{aligned}
$$

where $y$ is the dependent variable; $x$ is a matrix of explanatory variables; $u$ is the error term whose conditional quantile distribution equals zero, and Quant $\theta\left(y_{i} \backslash x_{i}\right)$ denotes the $\theta^{\text {th }}$ quantile of $y$ conditional on $x$. The distribution of the error term $u$ is left unspecified. An individual coefficient $\beta_{\theta j}$ associated with the $j^{\text {th }}$ independent variable in the vector $x_{i}$, called $x_{i j}$, could be interpreted as 'how $y_{i}$ in its $\theta^{\text {th }}$ conditional quantile reacts to a (ceteris paribus) marginal change in $x_{i}^{\prime}$. The QR method thus allows us to identify the effects of the covariates at different locations in the conditional distribution of the dependent variable.

The $\theta^{\text {th }}$ regression quantile estimate $\beta^{\wedge} \theta$, is the solution to the following minimisation problem:

$$
f(x)=a_{0}+\sum_{i=1}^{n}\left(a_{n} \cos \frac{n \pi x}{L}+b_{n} \sin \frac{n \pi x}{L}\right)
$$

Thus, this study obtains multiple sets of coefficient estimates with each set describing the relationship between the dependent variable and explanatory variables at a certain quantile of the dependent variable, i.e., the $25 \%, 50 \%, 75 \%$ and $90 \%$ quantiles.

In addition, a QR estimator minimises the weighted sum of absolute residuals rather than the sum of squared residuals. Thus, the estimated coefficient vector is not sensitive to outliers. As previously mentioned, QR is also particularly useful when the conditional distribution does not have a standard shape, such as an asymmetric, fat-tailed, or truncated distribution. Therefore, using mean regression alone is not accurate enough to draw reliable conclusions, and QR may perform more efficiently and robustly than OLS estimations. 


\subsection{Interpretation}

As noted, the conditional mean regression model predicts the average value of the outcome variable conditional on the independent variables. It is the mean of $Y$ conditional on the covariates $X$. A feature of the mean regression is that only one single estimate is derived to summarise the (average) relationship between the outcome variable and the model covariates. The estimates of the correlation between the dependent variable and the model covariates are assumed constant at all parts of the conditional distribution. Two issues arise in this context. First, the homogeneity assumption might not be valid and the restriction needs to be tested. Second, the investigator might be interested in outcomes other than the conditional mean.

In contrast, QR yields an estimator that predicts the conditional quantile of $Y$ based on the set of covariates $X$. There are many quantile values one can choose for $\mathcal{T}$. For example, when the quantile is $50 \%$ (i.e., the median) then $\mathcal{T}=0: 5$ and $=\mathrm{Q} 0: 5\left(Y_{i j} / X_{i}\right)$ describes the median of outcome of the response variable $Y_{i}$ (e.g., firm performance) conditional on $X_{i}$ (e.g., corporate governance, firm level variables, etc.). When the quantile is $\mathcal{T}=0: 25$, then Q0:25 $\left(Y_{i j} / X_{i}\right)$ predicts the 25 th percentile of $Y_{i}$ conditional on model covariates $X i$. And when the quantile is $\mathcal{T}=0: 75, \mathrm{Q} 0: 75\left(Y_{i j} / X_{i}\right)$ predicts the 75 th percentile of $Y_{i}$ conditional on $X_{i}$.

Importantly, QR allows for a range of different estimates to be derived that describe the conditional distribution of the outcome variable. Unlike the conditional mean regression (such as OLS), the QR does not require the assumption that the effect of covariate $X$ is constant. In fact, $\mathrm{QR}$ can be used to show those contexts when the conditional distribution is not homogenous. If estimates at different quantiles are significantly different from one another, the conditional distribution is shown not to be homogenous, contrary to what is assumed in classical least squares regression.

This study employs the OLS Pooled regression model as a basic model and compares the findings to alternative approaches i.e., regression models for panel data analysis (random and fixed effects) and QR models (Duppati et al., 2017).

The basic specification with controlling firm characteristics is expressed as below:

$$
\begin{aligned}
& Y_{t}=\propto+\beta_{1} \text { Gender }_{i t}+\beta_{2} \text { Board Size }_{i t}+\beta_{3} \text { Beta }_{i t}+\beta_{4} \text { Slack }_{i t}+\beta_{5} \text { Firm size }_{i t} \\
& +\beta_{6} \text { Asset Turnover }_{i t}+\beta_{7} \text { Firmage }_{i t}+\varepsilon_{i t}(1)
\end{aligned}
$$

where $Y_{t}$ is dependent variable and two proxies are used as performance variables: TQ ROA and stock returns.

$\mathrm{X}_{1 \mathrm{it}}$ is a vector of independent variables including board and firm characteristics slack (proportion of equity to debt), gender diversity, board size, firm size (total assets), asset turnover (sales to total assets), beta (market risk), sales and sales growth and the description of variables is shown in Table 1. To alleviate the potential bias caused by omitted variables, we control for other general firm characteristics including firm age, firm size, and leverage.

\section{Empirical findings}

The sample consisted of 69 listed New Zealand companies for the period 2005-2016. Table 2 provides the summary statistics. 
Table 2 Summary statistics of New Zealand listed firms for the period 2005-2016

\begin{tabular}{lcccc}
\hline Variable & Mean & Std. dev. & Min. & Max. \\
\hline Female & 0.769 & 0.809 & 0.000 & 3.000 \\
Board size & 6.066 & 1.630 & 2.000 & 11.000 \\
Risk & 120.897 & 338.450 & 0.006 & $3,566.862$ \\
Dividends & 19.362 & 18.503 & 1.000 & 77.000 \\
EPS & 140.806 & 83.552 & 4.000 & 316.000 \\
Firm size & 206.500 & 119.078 & 1.000 & 412.000 \\
Funds from operations & 396.811 & 230.034 & 1.000 & 802.000 \\
Leverage & 5.255 & 23.434 & 0.003 & 350.000 \\
ROA & 8.117 & 36.172 & 0.013 & 544.000 \\
TQ & 7.766 & 36.486 & 0.012 & 598.000 \\
Sales & 5.661 & 1.105 & 0.000 & 6.675 \\
Sales growth & 4.802 & 44.297 & -0.999 & 778.000 \\
\hline
\end{tabular}

To identify the impact of the gender reporting requirement on the gender diversity practices of the listed New Zealand companies, the study undertakes univariate analysis and classifies the data into two time periods, namely, the pre-reporting period (2005-2011) and the post-reporting period (2012-2016). The firms that have no female representation on boards are classified as 'No female' and those that have female representation on boards are referred as 'female'. The comparative t-statistics are given in Table 4. P-values are from the t-tests for mean comparison.

Table 3 Summary statistics of female representation on boards

\begin{tabular}{lcccc}
\hline Year & Mean & SD & Min. & Max. \\
\hline 2005 & 0.44 & 0.65 & 0 & 3 \\
2006 & 0.43 & 0.65 & 0 & 3 \\
2007 & 0.45 & 0.65 & 0 & 3 \\
2008 & 0.52 & 0.80 & 0 & 4 \\
2009 & 0.58 & 0.76 & 0 & 3 \\
2010 & 0.64 & 0.86 & 0 & 3 \\
2011 & 0.68 & 0.85 & 0 & 3 \\
2012 & 0.78 & 0.86 & 0 & 3 \\
2013 & 0.86 & 0.84 & 0 & 3 \\
2014 & 0.93 & 0.88 & 0 & 4 \\
2015 & 1.02 & 0.93 & 0 & 4 \\
2016 & 1.00 & 0.94 & 0 & 4 \\
\hline
\end{tabular}

Figure 1 indicates the female representations on boards has increased, but at a very slow pace (see also Table 3). It suggests that the government's gender diversity reporting requirement has had little impact so far. Policy makers should take note of this fact and explore options to make the reporting requirement more effective. Table 4 indicates that the boards without female representation are significantly better across various 
dimensions than those with the female representation in the pre-reporting period at the $1 \%$ level of significance. In the post-reporting period, it is opposite. Female representation on boards is significantly better than boards without female representation at the $1 \%$ level. There is a significant difference at $1 \%$ level of significance in the board size for those companies that had female representation and those that had no female representation in both the pre-and post-reporting periods.

Table 4 Comparative t-statistics of boards with and without female representation in the pre (2005-2011) and post (2012-2016) reporting requirement on gender diversity by New Zealand Exchange

\begin{tabular}{|c|c|c|c|c|c|c|}
\hline \multirow{2}{*}{ Variables } & \multicolumn{3}{|c|}{ Pre-reporting requirement } & \multicolumn{3}{|c|}{ Post-reporting requirement } \\
\hline & No female & Female & $p$-value & No female & Female & $p$-value \\
\hline Board size & 3.586 & 2.705 & $0.003 * * *$ & 2.368 & 3.904 & $0.000 * * *$ \\
\hline Female & 0.592 & 0.407 & $0.000 * * *$ & 0.185 & 0.365 & $0.000 * * *$ \\
\hline CSR & 0.257 & 0.234 & 0.406 & 0.185 & 0.365 & $0.000 * * *$ \\
\hline Firm size & 250 & 149 & $0.000 * * *$ & 183 & 247 & $0.016^{* *}$ \\
\hline Leverage & 1.827 & 1.448 & 0.674 & 0.79 & 1.458 & 0.308 \\
\hline Sales & 3.285 & 2.284 & $0.000 * * *$ & 2.268 & 3.5 & $0.000 * * *$ \\
\hline $\begin{array}{l}\text { Growth in } \\
\text { sales }\end{array}$ & 7.142 & 3.387 & 0.273 & 0.843 & 0.868 & 0.954 \\
\hline $\begin{array}{l}\text { Funds from } \\
\text { operations }\end{array}$ & 227 & 160 & $0.000 * * *$ & 169 & 273 & $0.000 * * *$ \\
\hline Beta & 0.126 & 0.177 & 0.691 & 0.142 & 0.341 & $0.077 *$ \\
\hline $\mathrm{SD}$ & 41.62 & 67.52 & 0.174 & 37.77 & 115.48 & $0.001 * * *$ \\
\hline ROA & 2.425 & 2.859 & 0.765 & 1.091 & 2.092 & 0.231 \\
\hline TQ & 2.864 & 2.542 & 0.834 & 1.095 & 1.526 & 0.379 \\
\hline Stock returns & 427 & 659 & 0.152 & 438 & 1207 & $0.000 * * *$ \\
\hline EPS & 91.08 & 54.54 & $0.000 * * *$ & 65.53 & 101.08 & $0.000 * * *$ \\
\hline DPS & 13.12 & 7.6 & $0.000 * * *$ & 11.15 & 12.6 & 0.379 \\
\hline Observations & 488 & & & 345 & & \\
\hline
\end{tabular}

Note: The asterisks $* * *$ and $* *$ indicate significance at $1 \%$ and $5 \%$ levels, respectively.

The size of those firms that had female representation on the board in the post-reporting period is significantly greater than the pre-reporting period at $5 \%$ level. Likewise, the CSR activities and sales of those firms that had female representation in the post-reporting period are significantly greater/higher than the pre-reporting period at the $1 \%$ level. The risk measures such as beta and standard deviation (stock returns) are higher in the case of the boards with female representation in the pre- and post-reporting periods and are significant at $10 \%$ and $1 \%$ levels. The financial performance, the ROA, TQ (not significant), stock returns (significant at 1\%) and EPS also are higher at the 1\% level in the companies with female representation on the board in the two reporting periods. Under the two time periods, the pre-reporting and the post-reporting periods, the results demonstrate superior share price performance for the companies with one or more women on the board. A key finding of this study is that companies with at least one woman on the board outperformed companies without any women on their boards in 
terms of share price performance, sales, earning per share and funds from operations over the course of the study period i.e., the past 12 years.

Figure 1 Graphical presentation of trends in female board representation (see online version for colours)

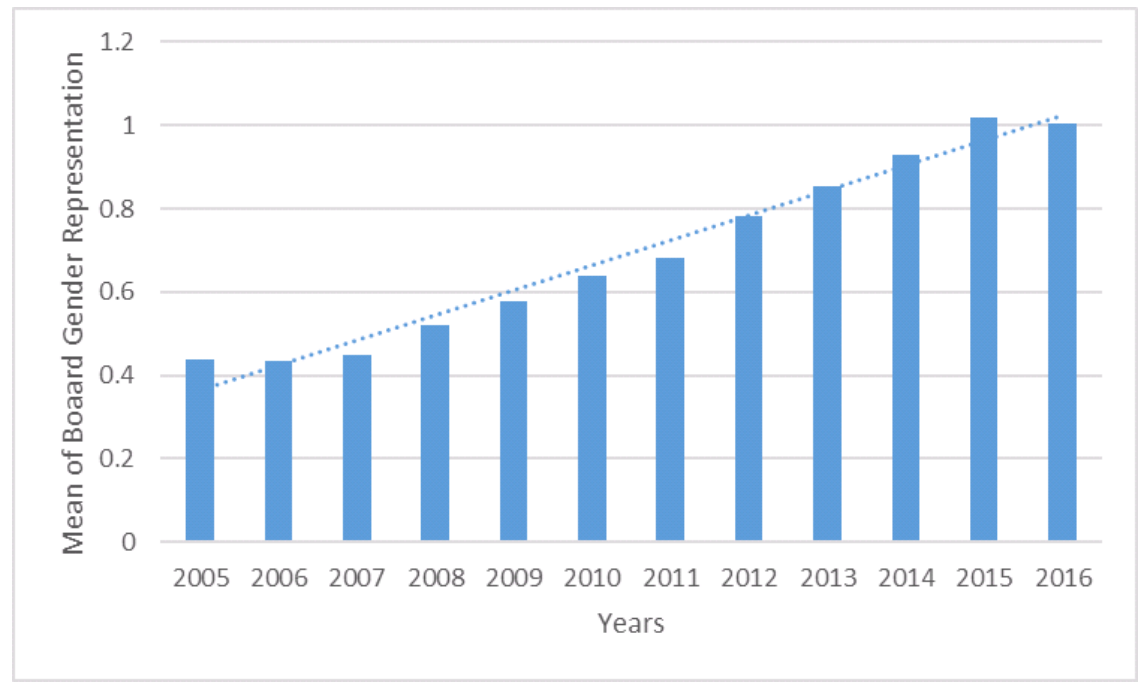

It is evident from the Table 5 that there was a significant correlation between female representation and firm size. The positive and significant (5\% level) correlation between the stock returns and beta suggested that the New Zealand firms studied were less risk averse than the average; they perceived risk as an opportunity and availed themselves of growth opportunities. This was corroborated with a significant and positive association of the slack financial variable, firm size with stock returns. There was no indication of multicollinearity between the variables, and none of them were closer to the 0.90 limit. It has been mentioned in the literature that when correlations between two variables exceed 0.80 or 0.90 (Judge et al., 1985) then it is considered as a multicollinearity problem for the model. As there was no multicollinearity problem between independent variables, the multiple regression model could be executed with these variables.

Consequently, the observed nonlinearities derived from conditional QR revealed considerable differences with regard to the impact of female representation on the board on the firm's performance at different levels of performance as measured by TQ.

Table 6 presents the relationship between gender diversity and performance in the period that covers the pre, during and post GFC. The female board representation in the post-financial crisis period is more significant and affects performance positively at the $1 \%$ level; the pre and during-periods of the GFC are insignificant. When the complete study period is considered, gender diversity is significant at the 5\% level. These results are robust to alternative estimation setting using $\mathrm{QR}$ as evident from Tables 7, 8, 9 and 10 . 
Table 5 The correlation matrix for the dependent and explanatory variables are presented below for the period 2005-2016

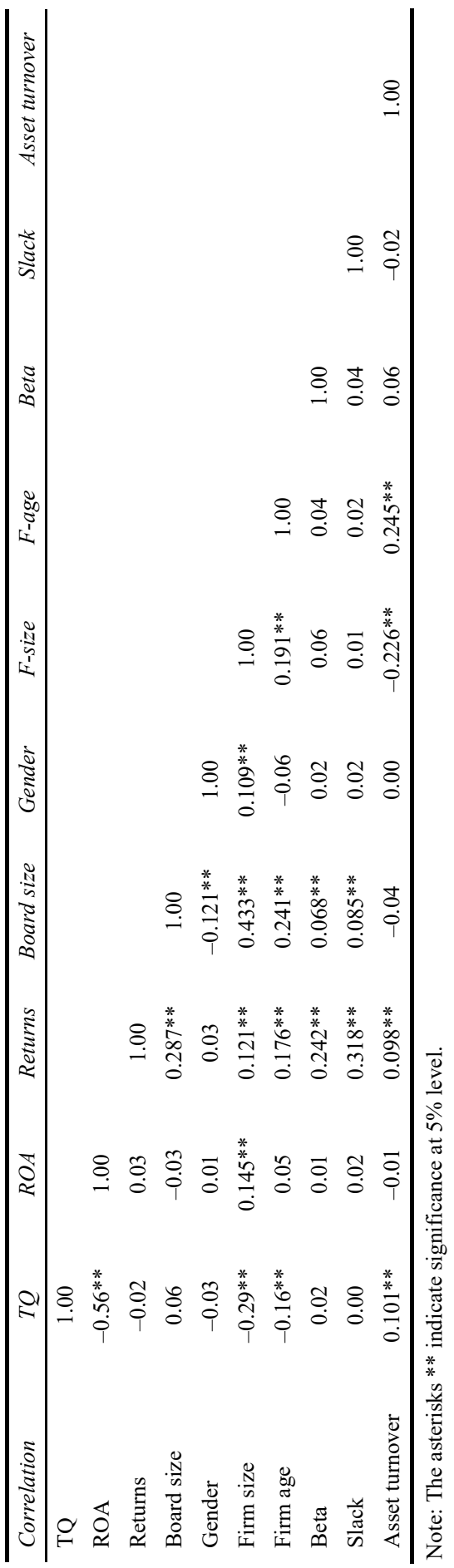


Table 6 The relationship between gender diversity and the performance in the GFC: pre (2005-2007), during (2008-2009), post (2010-2016) and the study period (2005-2016)

\begin{tabular}{|c|c|c|c|c|}
\hline & Pre-GFC & During-GFC & Post-GFC & Complete period \\
\hline \multirow{2}{*}{ Board size } & 1.059 & 0.086 & 0.057 & 0.438 \\
\hline & $(3.27)^{* * *}$ & -1 & $(1.94)^{*}$ & $(4.70)^{* * *}$ \\
\hline \multirow{2}{*}{$\begin{array}{l}\text { Gender } \\
\text { Diversity }\end{array}$} & 6.402 & -0.831 & 1.365 & 2.982 \\
\hline & -1.43 & -0.65 & $(3.59)^{* * *}$ & $(2.47)^{* *}$ \\
\hline \multirow{2}{*}{ Beta } & 0.146 & 0.018 & 0.012 & 0.017 \\
\hline & -0.56 & -1.49 & -1.42 & -0.46 \\
\hline \multirow{2}{*}{ Slack } & 0 & -0.112 & 0 & 0 \\
\hline & -0.85 & $(36.15)^{* * *}$ & -0.01 & -0.22 \\
\hline \multirow{2}{*}{ Asset turnover } & -0.943 & -0.051 & 0.225 & -0.119 \\
\hline & -1.54 & -0.17 & $(2.14)^{* *}$ & -0.52 \\
\hline \multirow{2}{*}{ Firm size } & -1.813 & -1.215 & -0.122 & -0.968 \\
\hline & $(7.07)^{* * *}$ & $(4.02)^{* * *}$ & $(2.32)^{* *}$ & $(9.89)^{* * *}$ \\
\hline \multirow{2}{*}{ Firm age } & -0.809 & 0.095 & -0.396 & -0.662 \\
\hline & -1.11 & -0.09 & $(2.76)^{* * *}$ & $(2.60)^{* * *}$ \\
\hline \multirow{2}{*}{ Constant } & 9.631 & 8.552 & 2.678 & 7.631 \\
\hline & $(3.17)^{* * *}$ & $(2.16)^{* *}$ & $(4.64)^{* * *}$ & $(7.06)^{* * *}$ \\
\hline $\mathrm{N}$ & 165 & 116 & 321 & 662 \\
\hline $\mathrm{R} 2$ & 0.47 & 0.154 & 0.268 & 0.343 \\
\hline \multicolumn{5}{|l|}{ Year effects } \\
\hline 2006 & & & & NS \\
\hline 2007 & & & & NS \\
\hline 2008 & & & & NS \\
\hline 2009 & & & & NS \\
\hline 2010 & & & & $(-2.24)^{* *}$ \\
\hline 2011 & & & & $(-2.62)^{* * *}$ \\
\hline 2012 & & & & $(-2.41)^{* *}$ \\
\hline 2013 & & & & NS \\
\hline 2014 & & & & NS \\
\hline 2015 & & & & NS \\
\hline 2016 & & & & NS \\
\hline
\end{tabular}

Notes: The asterisks $* * *, * *$ and $*$ indicate significance at $1 \%, 5 \%$ and $10 \%$ levels, respectively.

$\mathrm{T}$-values are shown in the parentheses. NS indicates not significant. 
Table 7 QR showing the relationship between gender diversity and the performance for the study periods 2005-2016

\begin{tabular}{lcccccc}
\hline Overall & $q 25$ & $q 40$ & $q 50$ & $q 60$ & $q 75$ & $q 90$ \\
\hline Board size & 0.01 & 0.03 & 0.04 & 0.06 & 0.12 & 0.31 \\
& -0.41 & $(2.19)^{* *}$ & $(1.78)^{*}$ & $(1.78)^{*}$ & $(3.23)^{* * *}$ & $(4.53)^{* * *}$ \\
Gender & 0.66 & 0.61 & 0.66 & 0.72 & 1.36 & 1.57 \\
diversity & $(4.54)^{* * *}$ & $(3.04)^{* * *}$ & $(3.11)^{* * *}$ & $(3.03)^{* * *}$ & $(4.20)^{* * *}$ & $(2.20)^{* *}$ \\
Beta & 0.01 & 0.00 & 0.00 & 0.00 & 0.00 & -0.03 \\
& -1.65 & -0.48 & 0.00 & -0.20 & -0.07 & -1.06 \\
Slack & 0.00 & 0.00 & 0.00 & 0.00 & 0.00 & 0.00 \\
& -0.05 & -0.04 & -0.02 & -0.02 & -0.01 & -0.04 \\
Asset & 0.07 & 0.06 & 0.13 & 0.19 & 0.22 & 0.25 \\
turnover & $(1.97)^{* *}$ & $(1.71)^{*}$ & $(2.55)^{* *}$ & $(2.48)^{* *}$ & $(2.77)^{* * *}$ & $(2.52)^{* *}$ \\
Firm size & -0.05 & -0.07 & -0.08 & -0.09 & -0.17 & -0.30 \\
& $(2.67)^{* * *}$ & $(3.92)^{* * *}$ & $(4.03)^{* * *}$ & $(3.11)^{* * *}$ & $(4.52)^{* * * *}$ & $(6.77)^{* * *}$ \\
Firm age & -0.18 & -0.17 & -0.16 & -0.21 & -0.24 & -0.20 \\
& $(4.41)^{* * *}$ & $(4.12)^{* * *}$ & $(4.49)^{* * *}$ & $(6.70)^{* * *}$ & $(4.58)^{* * *}$ & $(2.91)^{* * *}$ \\
cons & 1.54 & 1.64 & 1.71 & 1.89 & 2.28 & 2.40 \\
& $(12.60)^{* * *}$ & $(18.97)^{* * *}$ & $(15.22)^{* * *}$ & $(13.84)^{* * * *}$ & $(12.48)^{* * *}$ & $(7.89)^{* * *}$ \\
Observations & & & & & & 662.00 \\
Pseudo R2 & 0.088 & 0.08 & 0.083 & 0.093 & 0.106 & 0.11 \\
\hline
\end{tabular}

Notes: The asterisks $* * *, * *$ and $*$ indicate significance at $1 \%, 5 \%$ and $10 \%$ levels, respectively. $\mathrm{T}$-values are shown in the parentheses.

Table 8 QR showing the relationship between gender diversity and the performance in the post financial crisis period (2010-2016)

\begin{tabular}{lcccccc}
\hline Post-GFC & $q 25$ & $q 40$ & $q 50$ & $q 60$ & $q 75$ & $q 90$ \\
\hline Board size & -0.003 & 0.005 & 0.003 & 0.004 & 0.043 & 0.196 \\
& -0.2 & -0.29 & -0.16 & -0.14 & -0.64 & $(2.62)^{* * *}$ \\
Gender & 0.751 & 0.824 & 0.944 & 1.086 & 1.194 & 0.516 \\
Diversity & $(3.20)^{* * *}$ & $(3.10)^{* * *}$ & $(3.77)^{* * *}$ & $(2.90)^{* * *}$ & $(1.99)^{* *}$ & -0.99 \\
Beta & 0.009 & 0.007 & 0.005 & 0.015 & 0.012 & 0.055 \\
& -1.16 & -0.7 & -0.31 & -0.87 & -0.38 & -1.5 \\
Slack & 0 & 0 & 0 & 0 & 0 & 0 \\
& -0.23 & -0.19 & -0.21 & -0.18 & 0 & -0.01 \\
Asset & 0.055 & 0.051 & 0.093 & 0.123 & 0.267 & 0.5 \\
Turnover & -1.16 & -1.42 & $(2.93)^{* * *}$ & $(1.91)^{*}$ & $(3.27)^{* * *}$ & $(2.58)^{* *}$ \\
Firm size & -0.049 & -0.069 & -0.074 & -0.076 & -0.098 & -0.197 \\
& $(2.58)^{* *}$ & $(4.25)^{* * *}$ & $(4.57)^{* * *}$ & $(4.09)^{* * *}$ & $(2.39)^{* *}$ & $(4.91)^{* * *}$ \\
\hline
\end{tabular}

Notes: The asterisks $* * *, * *$ and $*$ indicate significance at $1 \%, 5 \%$ and $10 \%$ levels, respectively. $\mathrm{T}$-values are shown in the parentheses. 
Table 8 QR showing the relationship between gender diversity and the performance in the post financial crisis period (2010-2016) (continued)

\begin{tabular}{lcccccc}
\hline Post-GFC & $q 25$ & $q 40$ & $q 50$ & $q 60$ & $q 75$ & $q 90$ \\
\hline Firm age & -0.148 & -0.164 & -0.187 & -0.224 & -0.3 & -0.158 \\
& $(5.09)^{* * *}$ & $(4.69)^{* * *}$ & $(5.69)^{* * *}$ & $(5.52)^{* * *}$ & $(4.31)^{* * *}$ & -0.91 \\
Constant & 1.509 & 1.761 & 1.933 & 2.122 & 2.426 & 2.052 \\
& $(10.14)^{* * *}$ & $(10.35)^{* * *}$ & $(12.70)^{* * *}$ & $(12.60)^{* * *}$ & $(8.32)^{* * *}$ & $(5.24)^{* * *}$ \\
Pseudo R2 & 0.132 & 0.1321 & 0.133 & 0.139 & 0.152 & 0.154 \\
Observations & & & & & & \\
\hline
\end{tabular}

Notes: The asterisks $* * *, * *$ and $*$ indicate significance at $1 \%, 5 \%$ and $10 \%$ levels, respectively. $\mathrm{T}$-values are shown in the parentheses.

Table 9 QR showing the relationship between gender diversity and the performance in the pre-GFC (2005-2007)

\begin{tabular}{lcccccc}
\hline Pre-GFC & $q 25$ & $q 40$ & $q 50$ & $q 60$ & $q 75$ & $q 90$ \\
\hline Board size & 0.07 & 0.15 & 0.19 & 0.17 & 0.24 & 1.33 \\
Gender & -1.07 & $(2.19)^{* *}$ & $(2.27)^{* *}$ & $(1.69)^{*}$ & -1.48 & $(1.78)^{*}$ \\
Diversity & 0.41 & 1.21 & 2.38 & 2.22 & 3.30 & 3.04 \\
Beta & -0.58 & -1.36 & $(2.05)^{* *}$ & $(2.20)^{* *}$ & $(2.14)^{* *}$ & -0.31 \\
& -0.08 & -0.03 & -0.03 & -0.03 & -0.01 & -0.32 \\
Slack & -1.14 & -0.32 & -0.34 & -0.42 & -0.05 & -0.18 \\
& 0.00 & 0.00 & 0.00 & 0.00 & 0.00 & 0.00 \\
Asset & 0.00 & 0.00 & 0.00 & 0.00 & 0.00 & 0.00 \\
Turnover & 0.09 & 0.10 & 0.12 & 0.23 & 0.10 & -0.80 \\
Firm size & -1.36 & -1.40 & -0.82 & -1.41 & -0.43 & -0.86 \\
& -0.04 & -0.11 & -0.17 & -0.16 & -0.28 & -0.96 \\
Firm age & -0.68 & $(1.7)^{*}$ & $(1.84)^{*}$ & -1.54 & -1.83 & -1.78 \\
& -0.24 & -0.26 & -0.24 & -0.26 & -0.29 & -0.37 \\
Constant & $(2.24)^{* *}$ & $(2.94)^{* * *}$ & $(2.18)^{* *}$ & $(1.95)^{*}$ & -1.27 & -1.05 \\
Pseudo R2 & 1.50 & 1.59 & 1.76 & 1.95 & 2.78 & 3.25 \\
Observations & $(3.54)^{* * *}$ & $(3.15)^{* * *}$ & $(2.58)^{* *}$ & $(2.22)^{* *}$ & $(2.06)^{* *}$ & $(1.80)^{*}$ \\
\hline
\end{tabular}

Notes: The asterisks $* * *, * *$ and $*$ indicate significance at $1 \%, 5 \%$ and $10 \%$ levels, respectively. T-values are shown in the parentheses.

Tables 8, 9 and 10 report the estimation results regarding the impact of female board representation on firm performance using QR. It is evident from Table 8 that female representation affects firm performance positively across all the quantiles ranging from 25 th to 75 th in the post-crisis period. In Table 9, using TQ as a performance measure, female board representation is found to affect firm performance positively and significantly only for the 50th to 75 th quantile in the pre-crisis period. This finding suggests that female board representation helps improve the performance of firms with 
higher TQ. It is evident from Table 10 that female representation on the board had no significant effect on the performance during the GFC period.

Table 10 QR showing the relationship between gender diversity and the performance during the GFC period (2008-2009)

\begin{tabular}{lcccccc}
\hline During-GFC & $q 25$ & $q 40$ & $q 50$ & $q 60$ & $q 75$ & $q 90$ \\
\hline Board size & 0.03 & 0.08 & 0.10 & 0.10 & 0.14 & 0.37 \\
& -1.03 & -1.45 & -1.52 & -1.17 & -0.94 & -0.27 \\
Gender & 0.49 & 0.24 & 0.23 & 0.99 & 1.28 & 0.17 \\
Diversity & -1.80 & -0.46 & -0.40 & -1.61 & -1.49 & -0.03 \\
Beta & -0.03 & -0.02 & -0.01 & -0.01 & 0.00 & 0.06 \\
& -0.45 & -0.37 & -0.29 & -0.18 & -0.05 & -0.09 \\
Slack & -0.02 & -0.01 & -0.06 & -0.06 & -0.06 & -0.05 \\
& -0.64 & -0.53 & $(2.58)^{* * *}$ & $(2.75)^{* * *}$ & $(2.73)^{* * * *}$ & -0.56 \\
Asset & 0.04 & 0.04 & 0.00 & 0.12 & -0.03 & -0.03 \\
Turnover & -0.78 & -0.41 & -0.01 & -0.80 & -0.13 & -0.02 \\
Firm size & -0.04 & -0.06 & -0.11 & -0.13 & -0.20 & -0.44 \\
& -1.94 & -1.31 & $(2.32)^{* *}$ & -1.04 & -0.90 & -0.25 \\
Firm age & -0.18 & -0.21 & -0.10 & -0.12 & -0.12 & 0.09 \\
& $(3.99)^{* * *}$ & -1.89 & -0.87 & -1.01 & -0.67 & -0.10 \\
Constant & 1.28 & 1.34 & 1.30 & 1.48 & 1.99 & 2.08 \\
Pseudo R2 & $(5.43)^{* * *}$ & $(6.01)^{* * *}$ & $(5.94)^{* * *}$ & $(2.00)^{* *}$ & -1.54 & -0.25 \\
Observations & 0.11 & 0.09 & 0.12 & 0.16 & 0.20 & 0.25 \\
\hline
\end{tabular}

Note: The asterisks $* * *$ and $* *$ indicate significance at $1 \%$ and $5 \%$ levels, respectively.

$\mathrm{T}$-values are shown in the parentheses

Consequently, the observed nonlinearities derived from conditional QR revealed considerable differences with regard to the impact of female representation on the board on the firm's performance at different levels of performance as measured by TQ for the period covering financial crisis.

\section{Conclusions}

In this article, we contribute to the literature on board diversity and firm financial performance by offering new insights into the relationship between female representation on boards and financial performance, using data from New Zealand. Historically, New Zealand has been a country with few women directors; as a result, the Government of New Zealand mandated gender diversity reporting in 2012. This has led to emergent board gender diversity.

Overall, the results indicate that gender diversity on corporate boards positively impacts financial performance. Across multiple dimensions, boards with female representation in the post-reporting requirement period performed better than firms without female representation during the same period. Therefore, it can be construed that 
the gender-reporting requirement in New Zealand has had a positive impact. Female board representation in the post-financial crisis period is significant and has positively impacted performance. The results also show that the market has had a favourable perception of companies that have female representation on boards when the TQ was used as a performance proxy. In summary, this study's results suggest that increased female representation on boards likely enhances shareholder value.

\subsection{Limitations and suggestions for future research}

This study utilised panel data analysis and QR models to investigate the relationship between female board representation and firm financial performance for a balanced sample of New Zealand listed companies over the period 2005-2016. Only one performance measure, namely, TQ, was considered. While this is the most commonly used performance measure in related literature, future studies could consider including other performance measures.

This study used data only from listed companies in New Zealand. Given the fact that New Zealand is a country with unique demographic and ethnic characteristics, the results may or may not be applicable to other countries in the Western world. Unfortunately, despite the numerous studies that have documented benefits of having female board members, and the insights gained from the critical mass theory, some of the largest companies still have no women directors and only a small percentage of firms have more than two women directors. Policy makers should take note of this fact and consider other ways to enhance the gender diversity of boards, in addition to the reporting requirement. Given the fact that there is still no unanimity regarding the impact of female representation on corporate boards regarding performance, academic researchers should explore the nuances of this issue by using data from both developed and developing countries. The insights gained from these studies should enable policy makers to formulate appropriate strategies, which may likely help achieve a critical mass of female directors. This should have a positive impact on firm financial performance. The improvement of gender diversity would not only make the boardrooms more equitable, but would help companies create greater value for their shareholders. No matter whether it is the cause or the result of financial performance, it does appear that firms should seriously consider inducting more female directors, not just in the interest of equity and fairness, but from the desire to create greater wealth for shareholders.

\section{References}

Adams, R.B. and Ferreira, D. (2009) 'Women in the boardroom and their impact on governance and performance', Journal of Financial Economics, Vol. 94, No. 2, pp.291-309.

Adams, R.B., de Haan, J., Terjesen, S. and van Ees, H. (2015) 'Board diversity: moving the field forward', Corporate Governance: An International Review, Vol. 23, No. 2, pp.77-82.

Ahern, K. and Dittmar, A.K. (2012) 'The changing of the boards: the impact on firm valuation of mandated female board representation', Quarterly Journal of Economics, Vol. 127, No. 1, pp.137-197.

Bansal, N. and Sharma, A.K. (2019) 'Corporate governance and firm performance in an emerging economy context: new evidence from India', International Journal of Comparative Management, Vol. 2, No. 2, pp.123-147. 
Basu, S. and Markov, S. (2004) 'Loss function assumptions in rational expectations tests on financial analysts' earnings forecasts', Journal of Accounting and Economics, Vol. 38, Nos. 1-3, pp.171-203.

Bernasek, A. and Shwiff, S. (2001) 'Gender, risk, and retirement', Journal of Economic Issues, Vol. 35, No. 2, pp.345-356.

Bertrand, M., Duflo, E. and Mullainathan, S. (2004) 'How much should we trust differences-in-differences estimates?', The Quarterly Journal of Economics, Vol. 119, No. 1, pp.249-275.

Bilimoria, D. (2000) 'Building the business case for women corporate directors', in Burke, R.J. and Mattis, M. C. (Eds.): Women on Corporate Boards of Directors: International Challenges and Opportunities, pp.25-40, Kluwer Academic Press, Dordrecht, The Netherlands.

Bonn, I. (2004) 'Board structure and firm performance: evidence from Australia', Journal of Management \& Organization, Vol. 10, No. 1, pp.14-24.

Brown, D., Brown, D. and Anastasopoulos, V. (2002) 'Women on boards: not just the right thing but the 'bright" thing', The Conference Board of Canada, 341-02/REP.

Campbell, K. and Mínguez-Vera, A. (2008) 'Gender diversity in the boardroom and firm financial performance', Journal of Business Ethics, Vol. 83, No. 3, pp.435-451.

Carter, D.A., D'Souza, F., Simkins, B.J. and Simpson, W.G. (2010) 'The gender and ethnic diversity of US boards and board committees and firm financial performance', Corporate Governance: An International Review, Vol. 18, No. 5, pp.396-414.

Carter, D.A., Simkins, B.J. and Simpson, W.G. (2003) 'Corporate governance, board diversity, and firm value', Financial Review, Vol. 38, No. 1, pp.33-53.

Catalyst Organization (2011) [online] http://www.catalyst.org/knowledge/2011-catalyst-censusfortune-500-women-board-directors (accessed 1 October 2016).

Croson, R. and Gneezy, U. (2009) 'Gender differences in preferences', Journal of Economic Literature, Vol. 47, No. 2, pp.448-474.

Darmadi, S. (2011) Board Compensation, Corporate Governance, and Firm Performance in Indonesia [online] http://ssrn.com/abstract=1907103 (accessed 1 October 2016).

Dobbin, F. and Jung, J. (2011) 'Board diversity and corporate performance: filling in the gaps: corporate board gender diversity and stock performance: the competence gap or institutional investor bias?', NCL Review, Vol. 89, No. 3, pp.809-838.

Doldor, E., Vinnicombe, S., Gaughan, M. and Sealy, R. (2012) Gender Diversity on Boards: The Appointment Process and the Role of Executive Search Firms, Equality and Human Rights Commission Research Report 85.

Donaldson, L. (1990) 'The ethereal hand: organizational economics and management theory', Academy of Management Review, Vol. 15, No. 3, pp.369-381.

Donaldson, T. and Preston, L.E. (1995) 'The stakeholder theory of the corporation: concepts, evidence, and implications,' Academy of Management Review, Vol. 20, No. 1, pp.65-91.

Duppati, G., Sune, A. and Samanta, N. (2017) 'Corporate governance, research and development volatility and firm performance-evidence from Spain and Ireland', Cogent Economics \& Finance, Vol. 5, No. 1, https://doi.org/10.1080/23322039.2017.1317117.

Duppati, G.R., Scrimgeour, F. and Sune, A. (2019) 'Relevance of corporate boards in driving performance in the period that covers financial crisis', Corporate Governance: The International Journal of Business in Society, Vol. 19, No. 2, pp.321-338.

Dwyer, P.D., Gilkeson, J.H. and List, J.A. (2002) 'Gender differences in revealed risk taking: evidence from mutual fund investors', Economics Letters, Vol. 76, No. 2, pp.151-158.

Ely, K. and Waymire, G. (1999) 'Accounting standard-setting organizations and earnings relevance: longitudinal evidence from NYSE common stocks, 1927-93', Journal of Accounting Research, Vol. 37, No. 2, pp.293-317.

Erhardt, N.L., Werbel, J.D. and Shrader, C.B. (2003) 'Board director diversity and firm financial performance', Corporate Governance: An International Review, Vol. 11, No. 2, pp.102-111. 
Erkut, S., Kramer, V.W. and Konrad, A.M. (2008) 'Critical mass: does the number of women on a corporate board make a difference?’, in Vinnicombe, S., Singh, V., Burke, R., Bilimoria, D. and Huse, M. (Eds.): Women on Corporate Boards of Directors: International Research and Practice, pp.350-366, Edward Elgar Press, Cheltenham.

Essen, M., Engelen, P.J. and Carney, M. (2013) 'Does 'good' corporate governance help in a crisis? the impact of country- and firm-level governance mechanisms in the European financial crisis', Corporate Governance: An International Review, Vol. 21, No. 3, pp.201-224.

Eversheds LLP (2011) The Eversheds Board Report: Measuring the Impact of Board Composition on Company Performance. Eversheds LLP, UK.

Fama, E.F. (1980) 'Agency problems and the theory of the firm', Journal of Political Economy, Vol. 88, No. 2, pp.288-307.

Fama, E.F. and Jensen, M.C. (1983) 'Separation of ownership and control', The Journal of Law and Economics, Vol. 26, No. 2, pp.301-325.

Freeman, R.E. (2010) Strategic Management: A Stakeholder Approach, Cambridge University Press, Cambridge, UK.

Gul, F.A., Srinidhi, B. and Ng, A.C. (2011) 'Does board gender diversity improve the informativeness of stock prices?', Journal of Accounting and Economics, Vol. 51, No. 3, pp.314-338.

Gul, F.A., Srinidhi, B. and Tsui, J.S.L. (2008) Board Diversity and the Demand for Higher Audit Effort, Working Paper [online] http://ssrn.com/paper=1359450S (accessed 1 October 2016).

Hudgens, G.A. and Fatkin, L.T. (1985) 'Sex differences in risk taking: repeated sessions on a computer-simulated task', The Journal of Psychology, Vol. 119, No. 3, pp.197-206.

Human Rights Commission (2012) NZX Proposed Diversity Listing Rule, May [online] http://www.neon.org.nz (accessed May 2012).

Jensen, M.C. and Meckling, W.H. (1976) 'Theory of the firm: managerial behaviour, agency costs and ownership structure', Journal of Financial Economics, Vol. 3, No. 4, pp.305-360.

Joecks, J., Pull, K. and Vetter, K. (2013) 'Gender diversity in the boardroom and firm performance: what exactly constitutes a 'critical mass'?', Journal of Business Ethics, Vol. 118, No. 1, pp.61-72.

Johnson, J.E. and Powell, P.L. (1994) 'Decision making, risk and gender: are managers different?', British Journal of Management, Vol. 5, No. 2, pp.123-138.

Judge, G., Griffiths, W.E., Carter, R.H. and Lutkepohl, H. (1985) The Theory and Practice of Econometrics, 2nd ed., John Wiley \& Sons Publishers, New York.

Julizaerma, M.K. and Sori, Z.M. (2012) 'Gender diversity in the boardroom and firm performance of Malaysian public listed companies', Procedia - Social and Behavioral Sciences, December, Vol. 65, pp.1077-1085.

Jurkus, A.F., Park, J.C. and Woodard, L.S. (2011) 'Women in top management and agency costs', Journal of Business Research, Vol. 64, No. 2, pp.180-186.

Kanter, R.M. (1977) 'Some effects of proportions on group life', American Journal of Sociology, Vol. 82, No. 5, pp.965-990.

Kim, B., Burns, M.L. and Prescott, J.E. (2009) 'The strategic role of the board: the impact of board structure on top management team strategic action capability', Corporate Governance: An International Review, Vol. 17, No. 6, pp.728-743.

Kirsch, A. (2018) 'The gender composition of corporate boards: a review and research agenda', The Leadership Quarterly, Vol. 29, No. 2, pp.346-364.

Koenker, R. and Bassett, G. (1978) 'Regression quantiles', Econometrica, Vol. 46, No. 1, pp.33-50.

Koenker, R. and Hallock, K. (2001) 'Quantile regression: an introduction', Journal of Economic Perspectives, Vol. 15, No. 4, pp.43-56. 
Krishnan, H. and Park, D. (2005) 'A few good women - on top management teams', Journal of Business Research, Vol. 58, No. 12, pp.1712-1720.

Kumar, P. and Zattoni, A. (2016) 'Corporate governance, board gender diversity and firm performance', Corporate Governance: An International Review, Vol. 24, No. 4, pp.388-389.

Li, M.Y.L. and Hwang, N.C.R. (2011) 'Effects of firm size, financial leverage and R\&D expenditures on firm earnings: an analysis using quantile regression approach', Abacus, Vol. 47, No. 2, pp.182-204.

Low, D.C., Roberts, H. and Whiting, R.H. (2015) 'Board gender diversity and firm performance: empirical evidence from Hong Kong, South Korea, Malaysia and Singapore', Pacific-Basin Finance Journal, November, Vol. 35, Part A, pp.381-401.

Mansi, S.A., Maxwell, W.F. and Miller, D.P. (2004) 'Does auditor quality and tenure matter to investors? Evidence from the bond market', Journal of Accounting Research, Vol. 42, No. 4, pp.755-793.

Marimuthu, M. and Kolandaisamy, I. (2009) 'Ethnic and gender diversity in boards of directors and their relevance to financial performance of Malaysian companies', Journal of Sustainable Development, Vol. 2, No. 3, pp.139-148.

Martínez, M.D.C.V. and Rambaud, S.C. (2019) 'Women on corporate boards and firm's financial performance', Women's Studies International Forum, September-October, Vol. 76, https://doi.org/10.1016/j.wsif.2019.102251.

Mínguez-Vera, A. and Martin, A. (2011) 'Gender and management on Spanish SMEs: an empirical analysis', The International Journal of Human Resource Management, Vol. 22, No. 14, pp.2852-2873.

Mohan, N.J. and Chen, C.R. (2004) 'Are IPOs priced differently based on gender?', Journal of Behavioral Finance, Vol. 5, No. 1, pp.57-65.

Moncrief, W.C., Babakus, E., Cravens, D.W. and Johnston, M.W. (2000) 'Examining gender differences in field sales organizations', Journal of Business Research, Vol. 49, No. 3, pp.245-257.

New Zealand Human Rights Commission (2012) New Zealand Census of Women's Participation 2012, Wellington, Aotearoa New Zealand.

Nguyen, H. and Faff, R. (2007) 'Impact of board size and board diversity on firm value: Australian evidence', Corporate Ownership \& Control, Vol. 4, No. 2, pp.24-32.

Niederle, M. and Vesterlund, L. (2007) 'Do women shy away from competition? Do men compete too much?', Quarterly Journal of Economics, Vol. 122, No. 3, pp.1067-1101.

Pletzer, J.L., Nikolova, R., Kedzior, K.K. and Voelpel, S.C. (2015) 'Does gender matter? Female representation on corporate boards and firm financial performance-a meta-analysis', PLOS One, Vol. 10, No. 6, pp. 1-21.

Post, C. and Byron, K. (2015) 'Women on boards and firm financial performance: a meta-analysis', Academy of Management Journal, Vol. 58, No. 5, pp.1546-1571.

Robinson, G. and Dechant, K. (1997) 'Building a business case for diversity', Academy of Management Executive, Vol. 11, No. 3, pp.21-31.

Rose, C. (2007) 'Does female board representation influence firm performance? The Danish evidence', Corporate Governance: An International Review, Vol. 15, No. 2 pp.404-413.

Shanmuganathan, M. (2018) 'Corporate governance relationship with strategic management: a longitudinal case analysis of RELX Group (Elsevier)', International Journal of Comparative Management, Vol. 1, No. 3, pp.273-294.

Shrader, C.B., Blackburn, V.B. and Iles, P. (1997) 'Women in management and firm financial value: an exploratory study', Journal of Managerial Issues, Vol. 9, No. 3, pp.355-372.

Sjåfjell, B. (2014) 'Gender diversity in the board room \& its impacts: is the example of Norway a way forward?', Deakin Law Review, Vol. 20, No. 1, pp.25-51. 
Smith, N., Smith, V.R. and Verner, M. (2006) 'Do women in top management affect firm performance? a panel study of 2,500 Danish firms', International Journal of Productivity and Performance Management, Vol. 55, No. 7, pp.569-593.

Sunden, A.E. and Surette, B.J. (1998) 'Gender differences in the allocation of assets in retirement savings plans', The American Economic Review, Vol. 88, No. 2, pp.207-211.

Terjesen, S., Sealy, R. and Singh, V. (2009) 'Women directors on corporate boards: a review and research agenda', Corporate Governance: An International Review, Vol. 17, No. 3, pp.320-337.

Thams, Y., Bendell, B.L. and Terjesen, S. (2018) 'Explaining women's presence on corporate boards: the institutionalization of progressive gender-related policies', Journal of Business Research, May, Vol. 86, pp.130-140.

Torchia, M., Calabrò, A. and Huse, M. (2011) 'Women directors on corporate boards: from tokenism to critical mass', Journal of Business Ethics. Vol. 102, No. 2, pp.299-317, DOI: 10.1007/s10551-011-0815-z.

Wang, Y. and Clift, B. (2009) 'Is there a 'business case' for board diversity?', Pacific Accounting Review, Vol. 21, No. 2, pp.88-103.

Weber, A. and Zulehner, C. (2010) 'Female hires and the success of start-up firms', The American Economic Review, Vol. 100, No. 2, pp.358-361.

Wood, R.E., Whelan, J. and Sojo, V. (2013) 'Goals, goal orientations, strategies, and performance', in New Developments in Goal Setting and Task Performance, pp.114-138, Routledge, Taylor $\&$ Francis Group, New York.

Yang, P., Riepe, J., Moser, K., Pull, K. and Terjesen, S. (2019) 'Women directors, firm performance, and firm risk: a causal perspective', The Leadership Quarterly, in press, https://doi.org/10.1016/j.leaqua.2019.05.004. 